\title{
EFFECT OF USING GRANULATED STEEL SLAG IN CONCRETE MIXES AS AN FINE AGGREGATE ON COMPRESSIVE STRENGTH AND WORKABILITY
}

\author{
Akarsh $^{1}$, Sharath ${ }^{2}$, Vathsala M N ${ }^{3}$, Narayana $^{4}$ \\ ${ }^{1}$ UG Student, Civil Engineering Department, SJCIT, Chickballapur, Karnataka, India \\ ${ }^{2} U G$ Student, Civil Engineering Department, SJCIT, Chickballapur, Karnataka, India \\ ${ }^{3}$ Assistant Professor, Civil Engineering Department, SJCIT, Chickballapur, Karnataka, India \\ ${ }^{4}$ Professor \& HOD, Civil Engineering Department, SJCIT, Chickballapur, Karnataka, India
}

\begin{abstract}
Steel slag is a waste product generated during the production of steel. These wastes are disposed in the form of landfills causes an enormous amount of land pollution. So for the increasing demand to protect the normal environment, especially in build-up areas, the needs to use these wastes are very important. In this paper, two types of concrete mixes were prepared with the different mixes for each type i.e. low strength and high strength concrete namely M25 and M50 respectively. The compressive, split tensile and flexural properties of concrete containing steel slag are compared with that of concrete containing river sand and also manufactured sand. But in this paper only the effect of using granulated steel slag in concrete mixes as an fine agate on compressive strength and workability is discussed. The properties of steel slag are also verified with the addition of GGBS (Ground Granulated Blast Furnace slag) as a replacement for cement.
\end{abstract}

Keywords: River sand, steel slag, OPC, GGBS, M Sand, compressive strength. $* * *$

\section{INTRODUCTION}

The recent boom in construction industry has given rise for the demand of construction materials especially the river sand. For Mortar and concrete the most preferred fine aggregate is river sand. As river sand is mined from river beds from millions of years has greatly impact on environment. The restriction on sand mining by ministry of environment and to reduce the impact on environment, many alternative materials are using as substitute to river sand, namely the M-sand. M-sand is a crushed aggregate produced from hard granite stone which is cubically shaped with grounded edges, washed and graded with consistency to be used as a substitute of river sand. However M-sand or manufactured sand is also a natural material and has having quarrying and quality issues. To reduce impact on environment, alternative materials to be used as substitute to fine aggregate are being extensively investigated all over the world. The rapid growth of industrialization generates numerous kinds of waste by products. These waste byproducts are consumed by construction industry in making various construction materials. Slag which is a used in concrete, a waste generated by steel industry not only helps in reducing greenhouse gases but also helps in making ecofriendly material. During the production of iron and steel, fluxes (limestone and/or dolomite) are charged into blast furnace along with coke for fuel. Corbondioxide is produced when coke is combusted, which reduces ironore into molten iron product. During separation of molten steel, fluxing agents separate impurities and slag is produced. Slag is a non-metallic inert byproduct primarily consists of silicates, aluminoslicates, and calcium-alumina-silicates. The molten slag which aborbs much of the sulphur from the charge comprises about 20 percent by mass of iron production the schematic production details of slag are shown in fig1. Granulated slag is one of the proven suitable alternative materials for replacing natural sand/ crushed fine aggregate. The use of granulated slag as substitute to river sand is well established in developed countries and is in regular practice. In the present study the granulated slag is experimented for the usage of mortar.

\section{RESEARCH SIGNIFICANCE IN INDIAN CONTEXT}

Concrete being the largest man made material used on earth is continuously requiring good quality of aggregates in large volumes. A need was felt to identify potential alternative source of fine aggregate to fulfil the future growth aspiration of Indian construction industry. Use of steel slag as aggregate provides great opportunity to utilize this waste material as an alternative to normally available fine aggregates. The total steel production in India is about 72.20 million tones and the waste generated annually is around 18 million tones (considerably higher than the world average) but hardly $25 \%$ are being used mostly in cement production(information source, source, world steel association 2011 data, J P Morgan Ernst and Young analysis). 


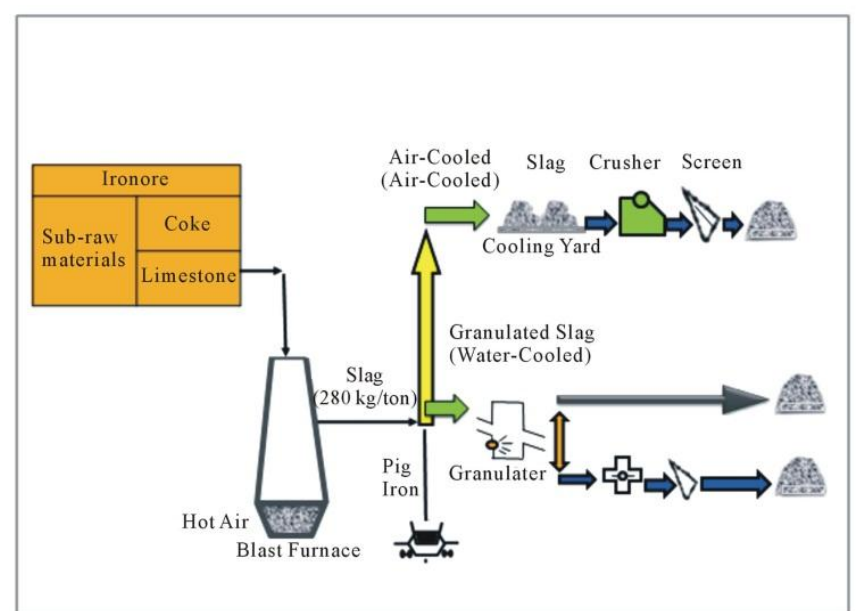

Fig 1 Schematic diagram of blast furnace operation and steel production

\section{OBJECTIVES}

In this project, the aim is to study the feasibility of steel slag as a viable replacement for river sand in concrete.

The compressive, split tensile and flexural properties of concrete containing steel slag are compared with that of concrete containing river sand and also manufactured sand.

The above mentioned tests are conducted for low strength and high strength concrete namely M25 and M50 respectively.

The properties of steel slag are also verified with the addition of GGBS (Ground Granulated Blast Furnace slag) as a replacement for cement.

Tests are conducted to evaluate the physical properties of steel slag such as water absorption, specific gravity, bulk density, sieve analysis and moisture content.

\section{EXPERIMENTAL RESULTS AND}

DISCUSSIONS

Compressive strength of M25 grade concrete with different mixes

\begin{tabular}{|c|c|}
\hline \multicolumn{2}{|c|}{ M25 Concrete Containing River Sand and Pure OPC } \\
\hline Age in Days & $\begin{array}{l}\text { Compressive strength } \\
\left(\mathrm{N} / \mathrm{mm}^{2)}\right.\end{array}$ \\
\hline 3 Days & 23.05 \\
\hline 7 Days & 38.09 \\
\hline 28 Days & 45.5 \\
\hline $\begin{array}{l}\text { M25 Concrete } \\
\text { OPC+GGBS }\end{array}$ & $\begin{array}{lll}\text { ng } & \text { River Sand and }\end{array}$ \\
\hline Age in Days & $\begin{array}{l}\text { Compressive } \\
\left(\mathrm{N} / \mathrm{mm}^{2)}\right.\end{array}$ \\
\hline 3 Days & 23.05 \\
\hline 7 Days & 38.09 \\
\hline 28 Days & 45.5 \\
\hline
\end{tabular}

\begin{tabular}{|l|l|}
\hline M25 Concrete Containing M-Sand and Pure OPC \\
\hline Age in Days & $\begin{array}{l}\text { Compressive } \\
\left(\mathrm{N} / \mathrm{mm}^{2)}\right.\end{array}$ \\
\hline 3 Days & 22.39 \\
\hline 7 Days & 31.7 \\
\hline 28 Days & 47.27 \\
\hline M25 Concrete Containing M-Sand and OPC+GGBS \\
\hline Age in Days & $\begin{array}{l}\text { Compressive } \\
\left(\mathrm{N} / \mathrm{mm}^{2)}\right.\end{array}$ \\
& 9.36 \\
\hline 3 Days & 18.07 \\
\hline 7 Days & 34.66 \\
\hline 28 Days & $\begin{array}{l}\text { Compressive } \\
\left(\mathrm{N} / \mathrm{mm}^{2)}\right.\end{array}$ \\
\hline M25 Concrete Containing Steel Slag and Pure OPC \\
\hline Age in Days & 18.25 \\
\hline 3 Days & 24.6 \\
\hline 7 Days & 38.43 \\
\hline 28 Days & $\begin{array}{l}\text { Compressive } \\
\left(\mathrm{N} / \mathrm{mm}^{2)}\right.\end{array}$ \\
\hline M25 Concrete Containing Steel Slag and OPC+GGBS \\
\hline Age in Days & 15.88 \\
\hline 3 Days & 21.42 \\
\hline 7 Days & 36.18 \\
\hline 28 Days & \\
\hline & strength \\
\hline
\end{tabular}

Compressive strength of M50 grade concrete with different mixes

\begin{tabular}{|c|c|}
\hline \multicolumn{2}{|c|}{ M50 Concrete Containing River Sand and Pure OPC } \\
\hline Age in Days & $\begin{array}{l}\text { Compressive strength } \\
\left(\mathrm{N} / \mathrm{mm}^{2)}\right.\end{array}$ \\
\hline 3 Days & 51.3 \\
\hline 7 Days & 69.84 \\
\hline 28 Days & 80.06 \\
\hline \multicolumn{2}{|c|}{$\begin{array}{l}\text { M50 Concrete Containing River Sand and } \\
\text { OPC+GGBS }\end{array}$} \\
\hline Age in Days & $\begin{array}{l}\text { Compressive strength } \\
\left(\mathrm{N} / \mathrm{mm}^{2)}\right.\end{array}$ \\
\hline 3 Days & 45.2 \\
\hline 7 Days & 58.67 \\
\hline 28 Days & 80.3 \\
\hline \multicolumn{2}{|c|}{ M50 Concrete Containing M-Sand and Pure OPC } \\
\hline Age in Days & $\begin{array}{l}\text { Compressive strength } \\
\left(\mathrm{N} / \mathrm{mm}^{2)}\right.\end{array}$ \\
\hline 3 Days & 61.07 \\
\hline 7 Days & 71.13 \\
\hline 28 Days & 81.6 \\
\hline \multicolumn{2}{|c|}{ M50 Concrete Containing M-Sand and OPC+GGBS } \\
\hline Age in Days & $\begin{array}{l}\text { Compressive strength } \\
\left(\mathrm{N} / \mathrm{mm}^{2)}\right.\end{array}$ \\
\hline 3 Days & 49.07 \\
\hline 7 Days & 64.33 \\
\hline 28 Days & 75.07 \\
\hline \multicolumn{2}{|c|}{ M50Concrete Containing Steel Slag and Pure OPC } \\
\hline Age in Days & $\begin{array}{l}\text { Compressive strength } \\
\left(\mathrm{N} / \mathrm{mm}^{2)}\right.\end{array}$ \\
\hline 3 Days & 37.67 \\
\hline 7 Days & 50.86 \\
\hline
\end{tabular}




\begin{tabular}{|l|ll|}
\hline 28 Days & 60.73 & \\
\hline $\begin{array}{l}\text { M50 Concrete } \\
\text { OPC+GGBS }\end{array}$ & \multicolumn{1}{|l|}{ Containing Steel Slag and } \\
\hline Age in Days & $\begin{array}{l}\text { Compressive } \\
\left(\mathrm{N} / \mathrm{mm}^{2}\right)\end{array}$ & strength \\
\hline 3 Days & 29.6 & \\
\hline 7 Days & 39.45 & \\
\hline 28 Days & 51.75 \\
\hline
\end{tabular}

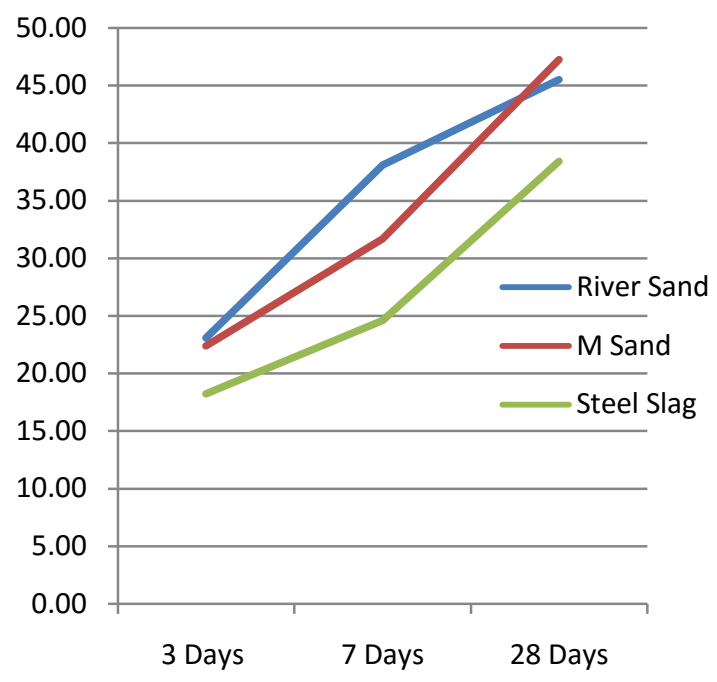

Graph 1: Compression strength of M25 River sand, M sand and Steel slag(OPC)

From the Graph 1 it can be observed that the gain in strength of concrete containing $100 \%$ steel slag is not as much as river sand and M-sand. But at the end of 28 days it can be observed that the sample containing steel slag has attained the target strength.

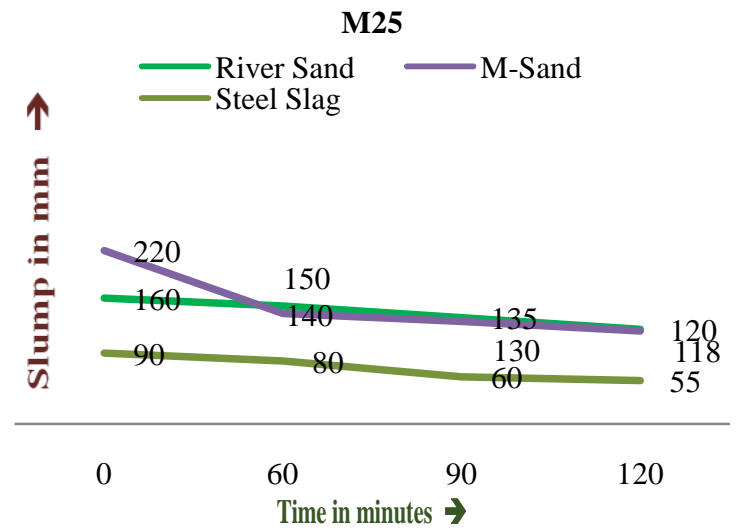

Graph 2: Slump graph(Workability)

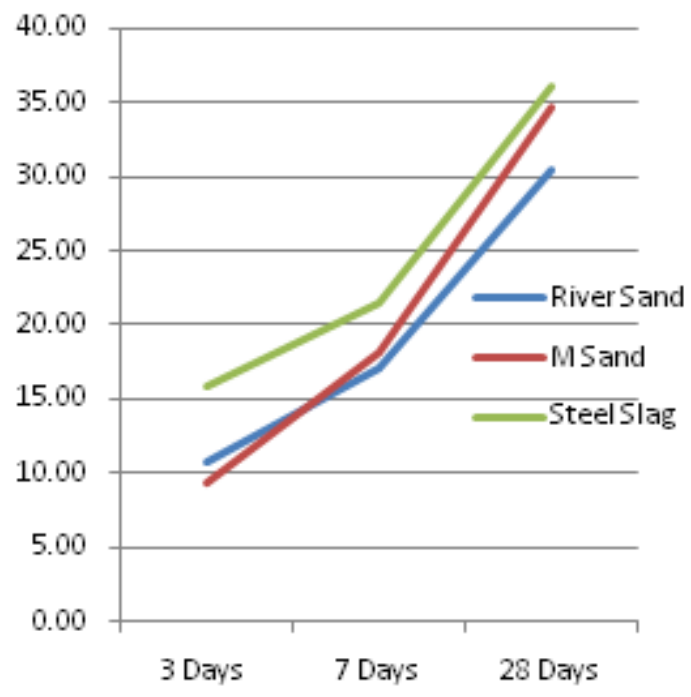

Graph 3: Compression strength of M25 River sand, M sand and Steel slag (OPC+GGBS)

From the Graph 3 it can be observed that the rate of gain of strength and the final attainment of strength in concrete containing steel slag with OPC+GGBS is relatively high compared to the samples containing River sand and $\mathrm{M}$ sand with OPC+GGBS. Which shows that concrete containing steel slag as the fine aggregate of low strength gains higher strength with GGBS as compared to concrete containing River sand and $M$ sand as fine aggregate. It can thus be said that the effect of GGBS on Steel Slag at low strengths is a positive one.

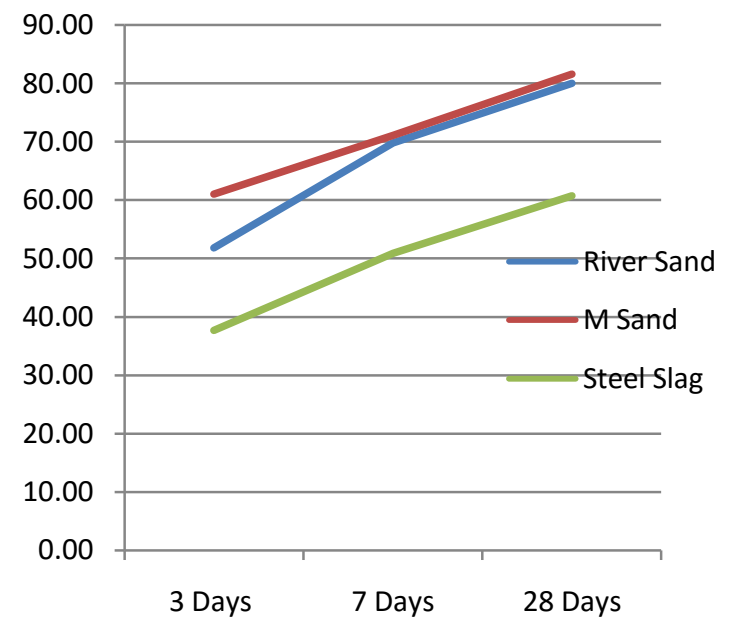

Graph 4: Compression strength of M50 River sand, M sand and Steel slag(OPC)

From the Graph 4 it can be observed that the concrete containing River sand and $\mathrm{M}$ sand as fine aggregate gain strength much faster and higher than that of Steel Slag. Although, the concrete containing Steel slag has attained the target strength. 


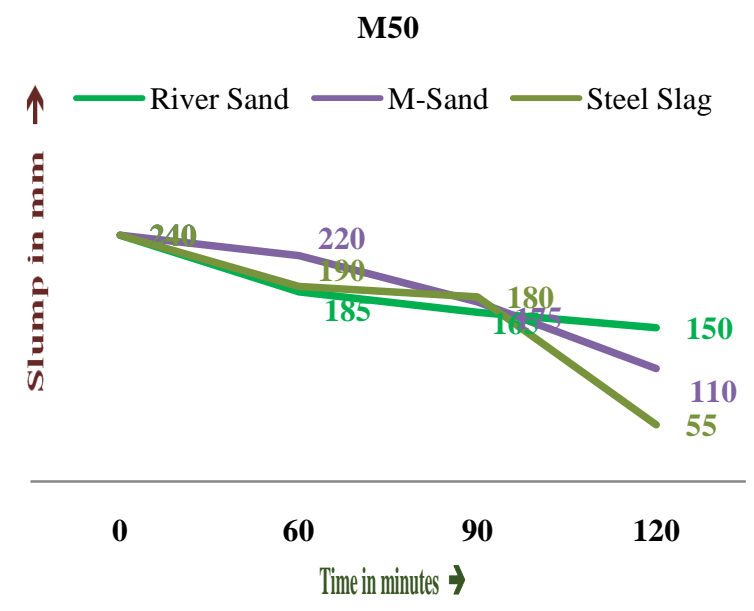

Graph 5: Slump graph(Workability)

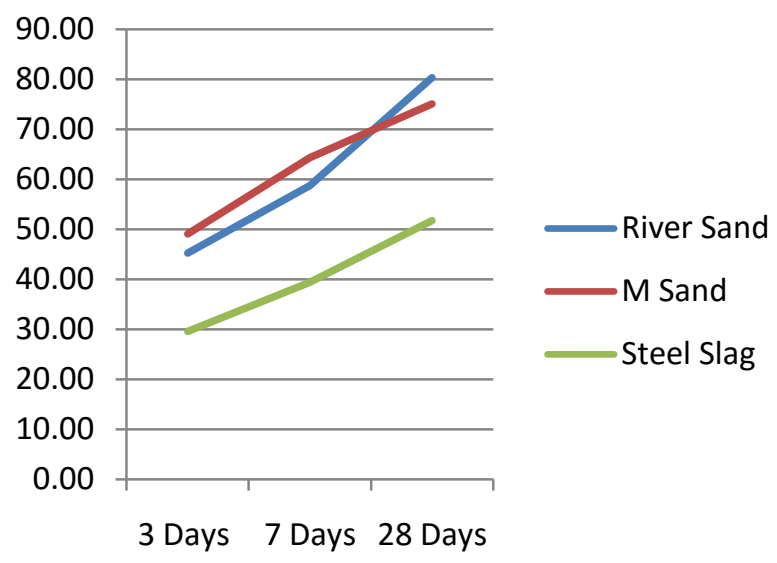

Graph 6: Compression strength of M25 River sand, M sand and Steel slag (OPC+GGBS)

From the Graph 6 it is not the same as that obtained for M25 with OPC+GGBS which indicates that at a lower strength, the concrete attains much higher strength with GGBS mixed with steel slag as compared to others and the same trend is not observed in high strength concrete like M50. Although, at 28th day the target strength is attained.

\section{CONCLUSION}

From the above results, it can be concluded that concrete containing steel slag mixed with GGBS and OPC gains higher strength for low strength concrete such as M25 as compared to concrete containing River sand and $\mathrm{M}$ sand as fine aggregates.

Also the gain in strength of concrete containing steel slag is not as high as compared to conventional concrete (those containing River sand and $\mathrm{M}$ sand) but at the end of 28 days the target strength was achieved showing reliability.

During the conduction of experiments it was observed that the workability of concrete containing steel slag was very low, as indicated by slump tests which have to be rectified by the trial and error method of finding the optimum requirement of admixtures.
Due to the lack of recognition of steel slag as a standard material in the codes, the lack of awareness is inevitable. As a result mix designs for steel slag are not available and hence further research should be conducted for the same.

From the slump graphs for M25 and M50 it can be observed that for M25 concrete the workability is low as compared to the river sand concrete. This can be attributed to the flakiness of the slag aggregates.

Since the amount of steel slag is reduced for M50 there is an appreciable increase in workability as compared to that of M25 which has higher amount of fines.

Over all it can be also observed that the target mean strength has been satisfactorily achieved which implies that the steel slag can be used as an eco-friendly alternative to river sand provided further tests and experiments are conducted in order to improve the inherent properties of concrete such as workability.

\section{REFERENCES}

[1] Srinivasarao, Ch.;Asadi, S.S and Kameswararao M, "An experimental study for identification of granulated blast furnace slag(GBFS) as an alternative to river sand and manufacturing sand as fine aggregate in concrete", International Journal of Applied Engineering Research, 2015.

[2] I.Yuksel, O. Ozkan and T. Bilir, "Use of granulated blast furnace slag in concrete as fine aggregate," ACI Materials Journal,vol. 103, no 3, 2006,pp.203-208.

[3] L. Zeghichi, "The effect of replacement of naturals aggregates by slag products on the strength of concrete," Asian Journal of Civil Engineering(Building and Housing), Vol 7, 2006, pp. 27-35.

[4] International Journal of Engineering Research and Applications (IJERA) ISSN: 2248-9622 www.ijera.com Vol. 2, Issue 5, September- October 2012, pp.1258-1264.

[5] International Journal of Engineering Research \& Technology (IJERT) ISSN: 2278-0181 Vol 2, issue 6 , june 2013.

\section{BIOGRAPHIES}

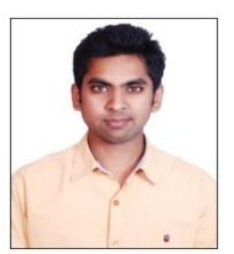

I Akarsh, pursued my Bachelor of Engineering in Civil Engineering from S J C Institute of Technology, Chickaballapur. Completed my dissertation work under the Guidance of Miss. Vathsala M N madam and Dr G Narayana sir.

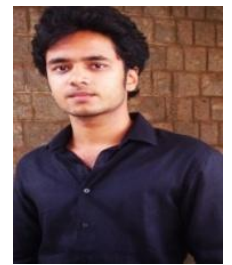

$\mathrm{He}$ is Sharath, pursued Bachelor of Engineering in Civil Engineering from $\mathrm{S} \mathrm{J}$ C Institute of Technology, Chickaballapur. Completed dissertation work under the Guidance of Miss. Vathsala M N madam and Dr G Narayana sir. 


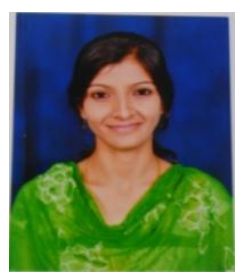

She is Vathsala M N Assistant Professor, Civil Engineering Department, S J C Institute of Technology, Chickaballapur. She is having more than 4 years of teaching experience.

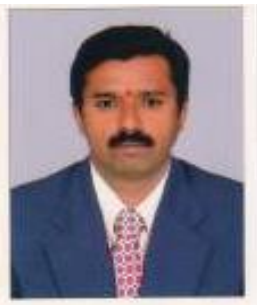

He is DR. G Narayana, Professor and Head of Department, Civil Engineering Department , S J C Institute of Technology, Chickaballapur. He has a wide experience in teaching and research in the field of Structural engineering. He is also a structural design consultant for many projects. 